\title{
PENGARUH KONSENTRASI DAN FREKUENSI PEMBERIAN ZAT PENGATUR TUMBUH GIBERELIN (GA3) TERHADAP PERTUMBUHAN DAN HASIL TANAMAN TERUNG (Solanum melongena L. cv. ANTABOGA-1)
}

\author{
Nova Triani", Vivin Putri Permatasari, Guniarti \\ Program Studi Agroteknologi Fakultas Pertanian Universitas Pembangunan Nasional "Veteran" Jawa Timur \\ `Email korespondensi: novatriani.agrotek@upnjatim.ac.id
}

\begin{abstract}
Eggplant (Solanum melongena $L$.) is a vegetable crop favored by the community and one of the efforts to increase production is by adding of gibberellin $\left(G A_{3}\right)$. This study aimed to determine the effect of concentration and application a frequency of $G A_{3}$ on the growth and yield of eggplant cv. Antaboga-1. The study was conducted at the UPT Food Crops, Horticulture and Plantation Office of Mantup Subdistrict, Lamongan Regency in January - April 2020. The research was arranged using a Factorial Complete Randomized Design with two factors, namely $\mathrm{GA}_{3}$ concentration $(K)$ consisted of $K_{0}=0 \mathrm{ppm} ; K_{I}=100 \mathrm{ppm} ; K_{2}=200 \mathrm{ppm} ; K_{3}=300 \mathrm{ppm}$ and application frequency of $G A_{3}(P)$ consisted of $P_{1}=2$ times; $P_{2}=3$ times; $P_{3}=4$ times. The results showed that the combination of 200 ppm and 2 times of application frequency significantly affected plant height (28-56 dap), number of leaves (35-49 dap), flowering age, total flower, total fruit number, total fruit weight and fruit weight per plant.

Keywords: application frequency, concentration, eggplant, flowering age, $G A_{3}$
\end{abstract}

\begin{abstract}
Abstrak. Terung (Solanum melongena L.) merupakan tanaman sayur yang digemari masyarakat dan salah satu upaya untuk meningkatkan produksi yakni dengan pemberian giberelin $\left(\mathrm{GA}_{3}\right)$. Penelitian ini bertujuan untuk mengetahui pengaruh konsentrasi dan frekuensi pemberian $\mathrm{GA}_{3}$ terhadap pertumbuhan dan hasil tanaman terung kultivar Antaboga-1. Penelitian dilakukan di UPT Dinas Tanaman Pangan, Hortikultura dan Perkebunan Kecamatan Mantup Kabupaten Lamongan pada bulan Januari - April 2020. Penelitian disusun menggunakan Rancangan Acak Lengkap Faktorial dengan dua faktor yaitu konsentrasi giberelin $(\mathrm{K})$ yang terdiri dari $\mathrm{K}_{0}=0 \mathrm{ppm}$; $\mathrm{K}_{1}=100 \mathrm{ppm} ; \mathrm{K}_{2}=200 \mathrm{ppm} ; \mathrm{K}_{3}=300 \mathrm{ppm}$ dan frekuensi pemberian giberelin $(\mathrm{P})$ yang terdiri dari $\mathrm{P}_{1}=2 \mathrm{kali}$; $\mathrm{P}_{2}=3$ kali $; \mathrm{P}_{3}=4$ kali. Hasil penelitian menunjukkan bahwa perlakuan kombinasi antara $200 \mathrm{ppm} \mathrm{GA}_{3}$ dan frekuensi pemberian 2 kali aplikasi, berpengaruh nyata terhadap tinggi tanaman (28-56 hst), jumlah daun (35-49 hst), umur berbunga, jumlah bunga total, jumlah buah total, dan berat buah per tanaman.
\end{abstract}

Kata kunci: frekuensi aplikasi, konsentrasi, terung, umur berbunga, $\mathrm{GA}_{3}$

\section{PENDAHULUAN}

Terung (Solanum melongena L.) merupakan salah satu komoditas sayuran penting sebagai bahan pangan sebagian besar masyarakat Indonesia dan merupakan tanaman asli tropis Indonesia (Uluputty, 2014). Terung memiliki banyak varietas dengan berbagai bentuk dan warna khas. Terung banyak mengandung vitamin dan gizi seperti vitamin $\mathrm{A}$, vitamin $\mathrm{B}$, vitamin $\mathrm{C}$, kalium, fosfor, zat besi, protein, lemak, dan karbohidrat (Sriyanto et al., 2015)

Produksi tanaman terung di Indonesia pada tahun 2015 yaitu 514.332 ton dari luas panen 45.919 ha, dengan hasil per hektarnya 11,20 ton. Sedangkan pada tahun 2016 produksinya 509.724 ton dari luas panen 44.829 ha, dengan hasil produksi per hektarnya 11,37 ton (Subdirektorat Statistik Hortikulura, 2018). Produksi terung nasional tiap tahun cenderung meningkat tetapi produksi terung di Indonesia masih rendah dibandingkan dengan negara Belanda, padahal buahnya banyak dikonsumsi masyarakat Indonesia (Firmansyah et al., 2017); (Setiawan, Junaedi, and Suhartanto 2019)

Hal ini disebabkan oleh luas lahan budidaya terung yang masih sedikit dan bentuk kultur budidaya yang masih bersifat sampingan dan belum intensif. Salah satu faktor penyebab rendahnya produksi tanaman adalah penerapan teknologi budidaya yang kurang tepat sehingga pertumbuhan tanaman tidak optimal. Salah satu upaya peningkatan produksi terung dapat dilakukan baik dari dalam maupun dari luar. Upaya dari luar yang dapat dilakukan adalah melakukan manipulasi lingkungan, diantaranya dengan perbaikan teknik budidaya, sedangkan upaya peningkatan dari dalam dapat dilakukan dengan manipulasi tanaman, salah satunya dengan pemberian zat pengatur tumbuh (ZPT). 
Zat Pengatur Tumbuh merupakan senyawa sintesis yang mempunyai aktivitas kerja yang sama seperti hormon tanaman (Seswita, 2020). Salah satu ZPT yang dapat memacu pertumbuhan tanaman dan produksi tanaman terung adalah giberelin $\left(\mathrm{GA}_{3}\right)$ (Rahman Zain et al., 2015).

Giberelin merupakan hormon yang mempercepat perkecambahan biji, membantu pembentukan tunas/embrio, perpanjangan batang, pertumbuhan daun, merangsang pembungaan, perkembangan buah, pemanjangan batang, pertumbuhan daun, merangsang pembungaan, perkembangan buah, mempengaruhi pertumbuhan dan diferensiasi akar. Giberelin mampu mempengaruhi sifat genetik dan proses fisiologi yang terdapat dalam tanaman, seperti pembungaan, partekanokarpi, dan mobilisasi karbohidrat selama masa perkecambahan berlangsung (Yasmin et al., 2014).

Penelitian ini bertujuan untuk mengetahui pengaruh konsentrasi dan frekuensi pemberian giberelin $\left(\mathrm{GA}_{3}\right)$ terhadap pertumbuhan dan hasil tanaman terung.

\section{METODE}

Penelitian dilaksanakan di lahan UPT Dinas Tanaman Pangan, Hortikultura dan Perkebunan Kecamatan Mantup Lamongan, pada bulan Januari-April 2020. Bahan yang digunakan adalah polybag, cocopeat, benih terung varietas Antaboga-1, air, tanah, Giberelin $\left(\mathrm{GA}_{3}\right)$, pupuk Urea, pupuk SP-36, pupuk $\mathrm{KCl}$, pupuk kandang, insektisida Furadan 3 GR, dan label. Alat yang digunakan dalam penelitian ini adalah, handsprayer, cangkul, ajir, gembor, penggaris, meteran, dan timbangan analitik.

Pelaksanaan penelitian meliputi persiapan benih, yaitu dengan memilih benih yang tenggelam dengan cara merendam benih dengan air selama 15 menit kemudian ditiriskan dengan kertas tisu. Persemaian dilakukan pada bak persemaian dengan kedalaman $\pm 2 \mathrm{~cm}$ pada media cocopeat dan diletakkan di tempat teduh. Pembibitan dilakukan hingga 21 hst atau tumbuh 2 helai daun. Media tanam terung dalam polybag berukuran $40 \mathrm{x} 40 \mathrm{~cm}$ yaitu tanah dan pupuk kandang dengan perbandingan 1:1. Penanaman dilakukan pada bibit berumur 21 hst atau tumbuh 2 helai daun. Kedalaman lubang tanam $\pm 5 \mathrm{~cm}$ di bagian tengah. Penyiraman dilakukan 2 kali sehari. Penyulaman dilakukan seminggu setelah masa tanam. Penyiangan dilakukan secara manual. Pemasangan ajir dilakukan sehari sebelum tanam dengan satu tanaman satu ajir. Perempelan tunas dilakukan pada tunas liar yang tumbuh di ketiak daun pertama sampai tunas di bawah bunga yang kedua. Pada saat tajuk tanaman telah menutupi seluruh daun bagian bawah, perempelan daun bawah cabang utama dilakukan. Perempelan juga dilakukan pada daun tua atau terserang penyakit. Pemupukan diberikan saat tanaman berumur 15 hst, 25 hst, dan 35 hst. Pada umur 15 hst tanaman diberi pupuk Urea $75 \mathrm{~kg} / \mathrm{ha}$ dan SP-36 $50 \mathrm{~kg} / \mathrm{ha}$. Umur 25 hst tanaman diberi pupuk Urea $75 \mathrm{~kg} / \mathrm{ha}$ dan $\mathrm{KCl} 75$ $\mathrm{kg} / \mathrm{ha}$. Umur tanaman 35 hst tanaman diberi pupuk Urea $75 \mathrm{~kg} / \mathrm{ha}$ dan $\mathrm{KCl} 100 \mathrm{~kg} / \mathrm{ha}$. Pengendalian hama dan penyakit menggunakan insektisida Confidor dengan dosis $2 \mathrm{cc} / \mathrm{l}$ air. Pemberian giberelin disesuaikan dengan perlakuan konsentrasi. Pelaksanaan dengan cara disemprotkan ke seluruh permukaan daun secara merata. Giberelin yag digunakan berupa larutan dengan kandungan bahan aktif $20 \%$ sehingga untuk $100 \mathrm{ppm}=0,5$ gram giberelin, $200 \mathrm{ppm}$ $=1$ gram giberelin, $300 \mathrm{ppm}=1,5$ gram giberelin. Pengenceran dilakukan dengan menambahkan air hingga 1 liter. Penyemprotan dilakukan sesuai perlakuan yaitu, $\mathrm{P}_{1}=$ frekuensi penyemprotan 2 kali (pada tanaman umur 7 dan $14 \mathrm{hst}$ ), $\mathrm{P}_{2}=$ frekuensi penyemprotan 3 kali (pada tanaman berumur 7, 14 dan $21 \mathrm{hst}), \mathrm{P}_{3}=$ frekuensi penyemprotan 4 kali (pada tanaman berumur 7, 14, 21, dan 28 hst). Pemanenan pertama dilakukan pada umur 57 hst. Pemanenan dilakukan dalam periode 7 hari sekali dan periode panen dilakukan 5 kali panen. Penelitian ini merupakan penelitian dalam 
polybag. Rancangan Acak Lengkap Faktorial yang terdiri dari 2 faktor, yaitu faktor pertama adalah konsentrasi giberelin $\left(\mathrm{GA}_{3}\right)$ dan faktor kedua adalah frekuensi pemberian giberelin $\left(\mathrm{GA}_{3}\right)$. Faktor pertama (konsentrasi giberelin $\left.\left(\mathrm{GA}_{3}\right)\right)$ terdiri dari 4 level yaitu 0 ppm, 100 ppm, 200 ppm dan 300 ppm. Faktor kedua (frekuensi pemberian giberelin $\left(\mathrm{GA}_{3}\right)$ ) terdiri dari 3 level yaitu 2 kali, 3 kali dan 4 kali. Sehingga didapatkan 12 kombinasi perlakuan yang masing-masing diulang 3 kali. Setiap ulangan menggunakan 3 sampel tanaman sehingga didapatkan total satuan percobaan 108 tanaman. Pengaruh perlakuan diuji dengan uji $F_{\text {hitung. }}$. Apabila nilai $F_{\text {hitung }}$ lebih besar daripada $F_{\text {tabel }}$ pada taraf $1 \%$ perlakuan dianggap sangat berbeda nyata. Jika nilai $F_{\text {hitung }}$ lebih besar daripada $F_{\text {tabel }}$ pada taraf $5 \%$ perlakuan dianggap berbeda nyata. Jika dari hasil analisis sidik ragam
RAL Faktorial diketahui terdapat perbedaan, maka dilakukan uji lanjut. Untuk pengujian lebih lanjut digunakan uji Beda Nyata Jujur (BNJ) $5 \%$ yang digunakan untuk membandingkan semua perlakuan.

\section{HASIL DAN PEMBAHASAN \\ Pengaruh Konsentrasi dan Frekuensi Pemberian GA3 terhadap Tinggi Tanaman Terung}

Hasil analisis ragam menunjukkan bahwa kombinasi perlakuan konsentrasi dan frekuensi pemberian ZPT Giberelin menunjukkan adanya pengaruh nyata terhadap tinggi tanaman terung pada 28-56 hst. Rata-rata tinggi tanaman terung pada berbagai kombinasi perlakuan konsentrasi dan frekuensi pemberian giberelin $\left(\mathrm{GA}_{3}\right)$ disajikan pada Tabel 1 .

Tabel 1. Rata-rata tinggi tanaman (cm) terung (Solanum melongena L.) pada kombinasi perlakuan konsentrasi dan frekuensi pemberian giberelin $\left(\mathrm{GA}_{3}\right)$ pada umur $28-56 \mathrm{hst}$

\begin{tabular}{|c|c|c|c|c|c|}
\hline \multirow{2}{*}{ Hari } & \multirow{2}{*}{$\begin{array}{l}\text { Perlakuan } \\
\text { Kombinasi }\end{array}$} & \multicolumn{4}{|c|}{ Tinggi Tanaman $(\mathrm{cm})$} \\
\hline & & $\mathrm{K}_{0}(0 \mathrm{ppm})$ & $\mathrm{K}_{1}(100 \mathrm{ppm})$ & $\mathrm{K}_{2}(200 \mathrm{ppm})$ & $\mathrm{K}_{3}(300 \mathrm{ppm})$ \\
\hline \multirow{3}{*}{$28 \mathrm{hst}$} & $\mathrm{P}_{1}(2 \mathrm{kali})$ & $11,17 \mathrm{a}$ & $25,56 \mathrm{~b}$ & $36,17 \mathrm{~b}$ & $31,72 \mathrm{~b}$ \\
\hline & $\mathrm{P}_{2}$ (3 kali) & $8,61 \mathrm{a}$ & $29,11 b$ & $31,28 \mathrm{~b}$ & $32,22 \mathrm{~b}$ \\
\hline & $\mathrm{P}_{3}$ (4 kali) & $9,89 \mathrm{a}$ & $27,56 \mathrm{~b}$ & $30,00 \mathrm{~b}$ & $31,17 \mathrm{~b}$ \\
\hline BNJ 5\% & \multicolumn{5}{|c|}{10,78} \\
\hline \multirow{3}{*}{35 hst } & $\mathrm{P}_{1}(2$ kali $)$ & $19,28 \mathrm{a}$ & $41,17 \mathrm{~b}$ & $57,28 \mathrm{~b}$ & $43,72 b$ \\
\hline & $\mathrm{P}_{2}$ (3 kali) & $15,61 \mathrm{a}$ & $44,56 \mathrm{~b}$ & $48,33 \mathrm{~b}$ & $46,06 \mathrm{~b}$ \\
\hline & $\mathrm{P}_{3}$ (4 kali) & $18,28 \mathrm{a}$ & $48,67 \mathrm{~b}$ & $47,56 \mathrm{~b}$ & $45,39 \mathrm{~b}$ \\
\hline BNJ 5\% & \multicolumn{5}{|c|}{19,76} \\
\hline \multirow{3}{*}{42 hst } & $\mathrm{P}_{1}(2$ kali $)$ & $34,78 \mathrm{a}$ & $66,89 \mathrm{~b}$ & $81,11 \mathrm{~b}$ & $63,83 \mathrm{~b}$ \\
\hline & $\mathrm{P}_{2}(3 \mathrm{kali})$ & $30,39 \mathrm{a}$ & $68,22 \mathrm{~b}$ & $73,50 \mathrm{~b}$ & $71,00 \mathrm{~b}$ \\
\hline & $\mathrm{P}_{3}$ (4 kali) & $35,56 \mathrm{a}$ & $72,17 \mathrm{~b}$ & $72,67 \mathrm{~b}$ & $72,94 \mathrm{~b}$ \\
\hline BNJ 5\% & \multicolumn{5}{|c|}{21,48} \\
\hline \multirow{3}{*}{49 hst } & $\mathrm{P}_{1}(2$ kali $)$ & $59,78 \mathrm{a}$ & $88,89 \mathrm{~b}$ & $108,78 \mathrm{~b}$ & $89,83 \mathrm{~b}$ \\
\hline & $\mathrm{P}_{2}$ (3 kali) & $48,17 \mathrm{a}$ & $85,06 \mathrm{~b}$ & $98,06 \mathrm{~b}$ & $89,72 \mathrm{~b}$ \\
\hline & $\mathrm{P}_{3}$ (4 kali) & $55,61 \mathrm{a}$ & $90,56 \mathrm{~b}$ & $92,67 \mathrm{~b}$ & $91,39 \mathrm{~b}$ \\
\hline BNJ 5\% & \multicolumn{5}{|c|}{23,96} \\
\hline \multirow{3}{*}{56 hst } & $\mathrm{P}_{1}$ (2 kali) & $72,89 \mathrm{a}$ & $108,83 \mathrm{~b}$ & $135,61 \mathrm{c}$ & $112,17 \mathrm{~b}$ \\
\hline & $\mathrm{P}_{2}$ (3 kali) & $66,17 \mathrm{a}$ & $111,33 \mathrm{~b}$ & $111,89 \mathrm{~b}$ & $107,67 \mathrm{~b}$ \\
\hline & $\mathrm{P}_{3}$ (4 kali) & $70,61 \mathrm{a}$ & $115,56 \mathrm{~b}$ & $112,06 \mathrm{~b}$ & $111,39 \mathrm{~b}$ \\
\hline BNJ 5\% & \multicolumn{5}{|c|}{10,97} \\
\hline
\end{tabular}

Keterangan : Angka-angka yang diikuti oleh huruf yang sama tidak berbeda nyata pada uji BNJ 5\%.

Tabel 1. menunjukkan kombinasi perlakuan antara konsentrasi dan frekuensi pemberian giberelin $\left(\mathrm{GA}_{3}\right)$ memberikan interaksi yang nyata. Hasil rata-rata dari tinggi tanaman terung yang lebih tinggi yaitu perlakuan konsentrasi 200 ppm $\mathrm{GA}_{3}$ dengan frekuensi pemberian 2 kali aplikasi pada umur tanaman yaitu 28-56 hst dan masingmasing sebesar $36,17 \mathrm{~cm} ; 57,28 \mathrm{~cm} ; 81,11$ $\mathrm{cm} ; 108,78 \mathrm{~cm}$ dan 135,61 cm. Sedangkan tinggi tanaman terung yang lebih rendah yaitu pada perlakuan konsentrasi 0 ppm $\mathrm{GA}_{3}$ 
dengan frekuensi pemberian 3 kali aplikasi pada umur tanaman yaitu 28-56 hst dan masing-masing sebesar $8,61 \mathrm{~cm} ; 15,61 \mathrm{~cm}$; $30,39 \mathrm{~cm} ; 48,17 \mathrm{~cm}$ dan $66,17 \mathrm{~cm}$.

Perlakuan konsentrasi giberelin 200 ppm $\mathrm{GA}_{3}$ dengan frekuensi pemberian 2 kali aplikasi dapat meningkatkan tinggi tanaman pada umur 28-56 hst, dimana angka yang lebih tinggi yaitu $135,61 \mathrm{~cm}$ dan mengalami peningkatan hingga 92,05\% dibandingkan dengan kontrol yaitu $70,61 \mathrm{~cm}$. Perbedaan tinggi tanaman terung yang terjadi diduga karena efek pemberian giberelin sehingga mampu mempengaruhi tekanan turgor sel sehingga bertambah memanjang.

Hal ini sesuai dengan Pertiwi et al., (2016) yang menyatakan bahwa hormon giberelin merupakan zat pengatur tumbuh karena dapat mengendalikan sintesis enzim dan memecahkan dormansi tunas pada sejumlah tanaman sehingga hormon giberelin sangat diperlukan dalam pertumbuhan untuk memacu aktivitas kambium dan merangsang pertumbuhan tinggi batang.

\section{Pengaruh Konsentrasi dan Frekuensi Pemberian GA3 terhadap Jumlah Daun Terung}

Hasil analisis ragam menunjukkan bahwa konsentrasi dan frekuensi pemberian giberelin $\left(\mathrm{GA}_{3}\right)$ menunjukkan interaksi nyata terhadap jumlah daun (helai) terung pada 3549 hst. Rata-rata jumlah daun terung pada berbagai perlakuan kombinasi konsentrasi dan frekuensi pemberian giberelin $\left(\mathrm{GA}_{3}\right)$ disajikan pada Tabel 2.

Tabel 2. Rata-rata jumlah daun terung (Solanum melongena L.) pada berbagai kombinasi perlakuan konsentrasi dan frekuensi pemberian giberelin $\left(\mathrm{GA}_{3}\right)$ pada Umur 35 hst, 42 hst dan 49 hst.

\begin{tabular}{|c|c|c|c|c|c|}
\hline \multirow[b]{2}{*}{ Hari } & \multirow{2}{*}{$\begin{array}{l}\text { Perlakuan } \\
\text { Kombinasi }\end{array}$} & \multicolumn{4}{|c|}{ Jumlah Daun (helai) } \\
\hline & & $\begin{array}{c}\mathrm{K}_{0} \\
(0 \mathrm{ppm})\end{array}$ & $\begin{array}{c}\mathrm{K}_{1} \\
(100 \mathrm{ppm})\end{array}$ & $\begin{array}{c}\mathrm{K}_{2} \\
(200 \mathrm{ppm}) \\
\end{array}$ & $\begin{array}{c}\mathrm{K}_{3} \\
(300 \mathrm{ppm}) \\
\end{array}$ \\
\hline \multirow{3}{*}{$35 \mathrm{hst}$} & $\mathrm{P}_{1}(2$ kali $)$ & $10 \mathrm{a}$ & $12 a b$ & $19 \mathrm{~b}$ & $13 \mathrm{ab}$ \\
\hline & $\mathrm{P}_{2}$ (3 kali) & $10 \mathrm{ab}$ & $13 \mathrm{ab}$ & $16 \mathrm{~b}$ & $13 \mathrm{ab}$ \\
\hline & $\mathrm{P}_{3}(4$ kali) & $10 \mathrm{ab}$ & $12 \mathrm{ab}$ & $15 \mathrm{~b}$ & $12 \mathrm{ab}$ \\
\hline BNJ 5\% & \multicolumn{5}{|c|}{5,18} \\
\hline \multirow{3}{*}{$42 \mathrm{hst}$} & $\mathrm{P}_{1}(2$ kali $)$ & $12 \mathrm{a}$ & $17 \mathrm{ab}$ & $24 \mathrm{~b}$ & $16 \mathrm{ab}$ \\
\hline & $\mathrm{P}_{2}(3 \mathrm{kali})$ & $13 \mathrm{ab}$ & $16 a b$ & $20 \mathrm{~b}$ & $16 \mathrm{ab}$ \\
\hline & $\mathrm{P}_{3}$ (4 kali) & $14 \mathrm{ab}$ & $17 \mathrm{ab}$ & $19 \mathrm{ab}$ & $16 \mathrm{ab}$ \\
\hline BNJ 5\% & \multicolumn{5}{|c|}{7,50} \\
\hline \multirow{3}{*}{$49 \mathrm{hst}$} & $\mathrm{P}_{1}(2 \mathrm{kali})$ & $16 \mathrm{a}$ & $22 \mathrm{bc}$ & $31 \mathrm{~d}$ & $21 \mathrm{bc}$ \\
\hline & $\mathrm{P}_{2}(3 \mathrm{kali})$ & $16 \mathrm{a}$ & $22 \mathrm{bc}$ & $26 \mathrm{c}$ & $22 \mathrm{bc}$ \\
\hline & $\mathrm{P}_{3}$ (4 kali) & $17 \mathrm{a}$ & $23 \mathrm{c}$ & $23 \mathrm{c}$ & $20 \mathrm{bc}$ \\
\hline BNJ 5\% & \multicolumn{5}{|c|}{3,27} \\
\hline
\end{tabular}

Keterangan : Angka-angka yang diikuti oleh huruf yang sama tidak berbeda nyata pada uji BNJ 5\%

Tabel 2. menunjukkan perlakuan kombinasi antara konsentrasi dan frekuensi pemberian giberelin $\left(\mathrm{GA}_{3}\right)$ memberikan interaksi yang nyata. Hasil rata-rata dari jumlah daun terung yang lebih tinggi yaitu pada perlakuan 200 ppm $\mathrm{GA}_{3}$ dengan frekuensi pemberian 2 kali pada umur tanaman yaitu 35-49 hst dan masing-masing sebesar 19 helai, 24 helai, dan 31 helai. Sedangkan jumlah daun terung yang lebih rendah yaitu pada perlakuan 0 ppm $\mathrm{GA}_{3}$ dengan frekuensi pemberian 2 kali pada umur tanaman yaitu 35-49 hst dan masing-masing sebesar 10 helai, 12 helai dan 16 helai.

Perlakuan konsentrasi giberelin 200 ppm dengan frekuensi pemberian 2 kali, juga dapat meningkatkan jumlah daun pada tanaman berumur 35-49 hst, dibandingkan dengan kontrol. Jumlah daun pada perlakuan konsentrasi giberelin 200 ppm dengan frekuensi pemberian 2 kali pada umur 49 hst mengalami peningkatan $93,75 \%$ 
dibandingkan dengan kontrol. Giberelin berfungsi dalam meningkatkan pembelahan sel sehingga dapat memperbesar ukuran daun. Hal ini dikarenakan giberelin disemprotkan ke daun tanaman secara langsung akan menyebabkan semakin banyaknya jumlah daun dikarenakan ketika stomata membuka, giberelin masuk ke dalam stomata dan membuat $\mathrm{GA}_{3}$ lebih cepat diserap. Giberelin dapat meningkatkan kadar auksin dalam tanaman yang berfungsi untuk deferensiasi sel dan organ tanaman (Arsy dan Barunawati, 2018). Aplikasi giberelin pada tanaman semangka juga terbukti dapat meningkatkan jumlah daun (Frasetya et al., 2018).

Aplikasi giberelin langsung ke daun dapat merangsang pertumbuhan daun. Daun pada tanaman tumbuh melekat pada cabang tanaman, semakin banyak jumlah cabang yang dihasilkan tanaman maka semakin banyak pula jumlah daun.

\section{Pengaruh Konsentrasi dan Frekuensi Pemberian GA3 terhadap Umur Berbunga Terung}

Hasil analisis ragam menunjukkan bahwa konsentrasi dan frekuensi pemberian giberelin $\left(\mathrm{GA}_{3}\right)$ menunjukkan terdapat interaksi nyata terhadap umur berbunga. Nilai interaksi rata-rata umur berbunga akibat konsentrasi dan frekuensi pemberian giberelin $\left(\mathrm{GA}_{3}\right)$ seperti pada Tabel 3 .

Tabel 3. Rata-rata umur berbunga terung (Solanum melongena L.) pada berbagai perlakuan kombinasi konsentrasi dan frekuensi pemberian giberelin $\left(\mathrm{GA}_{3}\right)$

\begin{tabular}{|c|c|c|c|c|c|}
\hline \multirow{2}{*}{$\begin{array}{l}\text { Perlakuan } \\
\text { Kombinasi }\end{array}$} & \multicolumn{3}{|c|}{ Umur Berbunga (hst) } & \multirow[b]{2}{*}{$\mathrm{K}_{3}(300 \mathrm{ppm})$} & \multirow{2}{*}{ Rataan } \\
\hline & $\mathrm{K}_{0}(\mathrm{ppm})$ & $\mathrm{K}_{1}(100 \mathrm{ppm})$ & $\mathrm{K}_{2}(200 \mathrm{ppm})$ & & \\
\hline $\mathrm{P}_{1}(2 \mathrm{kali})$ & $40,56 \mathrm{~d}$ & 37,56 b & $35,56 \mathrm{a}$ & $38,89 \mathrm{c}$ & $38,14 \mathrm{a}$ \\
\hline $\mathrm{P}_{2}(3$ kali $)$ & $40,22 \mathrm{c}$ & $37,44 \mathrm{~b}$ & $37,22 \mathrm{~b}$ & $38,56 \mathrm{~b}$ & $38,36 \mathrm{a}$ \\
\hline $\mathrm{P}_{3}(4$ kali $)$ & $40,67 \mathrm{~d}$ & $38,44 \mathrm{~b}$ & $37,67 \mathrm{~b}$ & $38,56 \mathrm{~b}$ & $38,84 \mathrm{a}$ \\
\hline Rataan & $40,48 \mathrm{c}$ & $37,81 \mathrm{ab}$ & $36,82 \mathrm{a}$ & $38,67 \mathrm{~b}$ & \\
\hline BNJ 5\% & & & & & \\
\hline
\end{tabular}

Keterangan : Angka-angka yang diikuti oleh huruf yag sama tidak berbeda nyata pada uji BNJ 5\%

Hasil penelitian menunjukkan pemberian 200 ppm $\mathrm{GA}_{3}$ dengan frekuensi pemberian 2 kali dapat berpengaruh nyata terhadap umur berbunga tanaman terung. Terung yang diberi perlakuan giberelin lebih cepat berbunga dibandingkan tanaman kontrol. Tanaman terung yang diberi konsentrasi 200 ppm $\mathrm{GA}_{3}$ dengan frekuensi pemberian 2 kali aplikasi dapat berbunga lebih awal yaitu pada 35,56 hst dan dapat meningkatkan $14,37 \%$ pembungaan. Tanaman terung yang telah diberi aplikasi giberelin berbunga lebih cepat yaitu 5 hari (36 hst) dibandingkan kontrol. Sedangkan perlakuan kontrol tanpa giberelin atau $0 \mathrm{ppm}$ berbunga pada 41 hst. Giberelin yang diaplikasikan saat awal berbunga berperan dalam proses penggiatan pembungaan (Yasmin et al., 2014). Dari hasil yang diperoleh terbukti bahwa giberelin dapat memacu pembungaan. Hal ini dikarenakan $\mathrm{GA}_{3}$ berpengaruh terhadap diferensiasi sel (Yasmin et al., 2014). Tanaman yang kekurangan giberelin menunjukkan penampilan kerdil dan pembungaan yang terlambat (Achard et al., 2008).

\section{Pengaruh Konsentrasi dan Frekuensi Pemberian GA3 terhadap Jumlah Bunga Total Per Tanaman Terung}

Hasil analisis ragam menunjukkan bahwa terdapat interaksi nyata antara konsentrasi dan frekuensi pemberian giberelin $\left(\mathrm{GA}_{3}\right)$ terhadap jumlah bunga total per tanaman terung. Nilai interaksi rata-rata jumlah bunga total per tanaman akibat perlakuan konsentrasi dan frekuensi pemberian giberelin $\left(\mathrm{GA}_{3}\right)$ pada Tabel 4. 
Tabel 4. Rata-rata jumlah bunga total per tanaman terung (Solanum melongena L.) pada berbagai perlakuan kombinasi konsentrasi dan frekuensi pemberian giberelin $\left(\mathrm{GA}_{3}\right)$

\begin{tabular}{cccccc}
\hline Perlakuan & \multicolumn{3}{c}{ Jumlah Bunga (bunga) } & \multirow{2}{*}{ Rataan } \\
\cline { 2 - 5 } Kombinasi & $\mathrm{K}_{0}(\mathrm{ppm})$ & $\mathrm{K}_{1}(100 \mathrm{ppm})$ & $\mathrm{K}_{2}(200 \mathrm{ppm})$ & $\mathrm{K}_{3}(300 \mathrm{ppm})$ & \\
\hline $\mathrm{P}_{1}(2 \mathrm{kali})$ & $17 \mathrm{ab}$ & $23 \mathrm{~b}$ & $27 \mathrm{c}$ & $20 \mathrm{~b}$ & $21,75 \mathrm{~b}$ \\
$\mathrm{P}_{2}(3 \mathrm{kali})$ & $17 \mathrm{ab}$ & $19 \mathrm{ab}$ & $23 \mathrm{~b}$ & $19 \mathrm{ab}$ & $19,5 \mathrm{ab}$ \\
$\mathrm{P}_{3}$ (4 kali) & $16 \mathrm{a}$ & $19 \mathrm{~b}$ & $20 \mathrm{~b}$ & $19 \mathrm{~b}$ & $18,5 \mathrm{a}$ \\
\hline Rataan & $16,67 \mathrm{a}$ & $20,33 \mathrm{~b}$ & $23,33 \mathrm{c}$ & $19,33 \mathrm{~b}$ & \\
\hline BNJ 5\% & \multicolumn{5}{c}{2,34} \\
\hline
\end{tabular}

Keterangan : Angka-angka yang diikuti oleh huruf yang sama tidak berbeda nyata pada uji BNJ 5\%.

Tabel 4. menunjukkan perlakuan kombinasi antara konsentrasi dan frekuensi pemberian giberelin $\left(\mathrm{GA}_{3}\right)$ memberikan interaksi yang nyata. Hasil rata-rata dari jumlah bunga total per tanaman terung yang lebih tinggi yaitu pada perlakuan konsentrasi 200 ppm $\mathrm{GA}_{3}$ dengan frekuensi pemberian 2 kali pada tanaman terung yaitu 27 bunga. Sedangkan jumlah bunga total per tanaman terung yang lebih rendah yaitu pada perlakuan konsentrasi 0 ppm $\mathrm{GA}_{3}$ dengan frekuensi pemberian 4 kali yaitu sebesar 16 bunga. Pemberian giberelin dapat meningkatkan jumlah bunga (Yasmin et al., 2014)

Perlakuan konsentrasi 200 ppm GA 3 dengan frekuensi pemberian sebanyak 2 kali dapat meningkatkan jumlah bunga total keseluruhan tanaman yaitu 27 bunga dibandingkan dengan kontrol yaitu konsentrasi 0 ppm sebanyak 17 bunga dan jumlah bunga mengalami peningkatan hingga $58,82 \%$. Hal ini disebabkan karena giberelin diduga dapat mengurangi kerontokan bunga sehingga bunga dapat mekar dengan

Tabel 5. Rata-rata jumlah buah total per tanaman terung (Solanum melongena L.) pada berbagai perlakuan kombinasi konsentrasi dan frekuensi pemberian giberelin $\left(\mathrm{GA}_{3}\right)$

\begin{tabular}{|c|c|c|c|c|c|}
\hline \multirow{2}{*}{$\begin{array}{l}\text { Perlakuan } \\
\text { Kombinasi }\end{array}$} & \multicolumn{3}{|c|}{ Jumlah Buah Total (buah) } & \multirow[b]{2}{*}{$\mathrm{K}_{3}(300 \mathrm{ppm})$} & \multirow{2}{*}{ Rataan } \\
\hline & $\mathrm{K}_{0}(\mathrm{ppm})$ & $\mathrm{K}_{1}(100 \mathrm{ppm})$ & $\mathrm{K}_{2}(200 \mathrm{ppm})$ & & \\
\hline $\mathrm{P}_{1}$ (2 kali) & $11 \mathrm{ab}$ & $15 \mathrm{bc}$ & $18 \mathrm{c}$ & $13 \mathrm{ab}$ & $14,25 \mathrm{a}$ \\
\hline $\mathrm{P}_{2}(3 \mathrm{kali})$ & $10 \mathrm{a}$ & $14 \mathrm{bc}$ & $14 \mathrm{~b}$ & $13 \mathrm{ab}$ & $12,75 \mathrm{a}$ \\
\hline $\mathrm{P}_{3}(4$ kali $)$ & $12 \mathrm{ab}$ & $13 a b$ & $14 \mathrm{~b}$ & $13 \mathrm{ab}$ & $13 \mathrm{a}$ \\
\hline Rataan & $11 \mathrm{a}$ & $14 \mathrm{~b}$ & $15,33 \mathrm{~b}$ & $13 \mathrm{ab}$ & \\
\hline BNJ 5\% & \multicolumn{4}{|c|}{2,96} & \\
\hline
\end{tabular}

Keterangan : Angka-angka yang diikuti oleh huruf yang sama tidak berbeda nyata pada uji BNJ 5\%. sempurna. Pemberian giberelin dapat berperan pada proses penggiatan pembungaan dan menurunkan absisi bunga sehingga jumlah bunga mengalami peningkatan (Yasmin et al., 2014). Efek penting dari giberelin adalah stimulasi sel generatif untuk sering membelah (Bose, 1959). Jumlah bunga yang banyak juga dapat menghasilkan jumlah buah terbentuk lebih banyak (Yasmin et al., 2014).

\section{Pengaruh Konsentrasi dan Frekuensi Pemberian GA3 terhadap Jumlah Buah Total per Tanaman Terung}

Hasil analisis ragam menunjukkan bahwa konsentrasi dan frekuensi pemberian giberelin $\left(\mathrm{GA}_{3}\right)$ menunjukkan terdapat interaksi nyata terhadap jumlah buah total per tanaman terung. Nilai interaksi rata-rata jumlah buah total per tanaman akibat perlakuan konsentrasi dan frekuensi pemberian giberelin $\left(\mathrm{GA}_{3}\right)$ terdapat pada Tabel 5. 
Tabel 5. menunjukkan perlakuan kombinasi antara konsentrasi dan frekuensi pemberian giberelin $\left(\mathrm{GA}_{3}\right)$ memberikan interaksi yang nyata. Hasil rata-rata dari jumlah buah total per tanaman terung yang lebih tinggi yaitu pada perlakuan konsentrasi 200 ppm $\mathrm{GA}_{3}$ dengan frekuensi pemberian sebanyak 2 kali pada tanaman terung yaitu 18 buah. Sedangkan jumlah buah total per tanaman terung yang lebih rendah yaitu pada perlakuan konsentrasi $0 \mathrm{ppm}$ dan frekuensi pemberian 3 kali aplikasi yaitu sebesar 10 buah. Tetapi antara perlakuan konsentrasi 200 ppm GA 3 dengan frekuensi pemberian 2 kali menunjukkan hasil yang tidak berbeda nyata dengan konsentrasi 100 ppm $\mathrm{GA}_{3}$ dengan frekuensi pemberian 2 kali. Sehingga dengan perlakuan konsentrasi 100 ppm GA 3 dengan frekuensi pemberian 2 kali lebih efisien. Persentase peningkatan jumlah buah total dibandingkan kontrol sebesar $80 \%$.

Jumlah total buah panen tiap tanaman terung, secara langsung atau tidak langsung akan menentukan total bobot buah tiap tanaman. Pemberian konsentrasi dan frekuensi pemberian giberelin mampu membentuk buah tanaman dan berat buah. Rolistyo et al. (2014) menyatakan bahwa pemberian giberelin $\left(\mathrm{GA}_{3}\right)$ pada tanaman tomat secara nyata meningkatkan bobot segar buah dan jumlah buah.

\section{Pengaruh Konsentrasi dan Frekuensi Pemberian GA3 terhadap Berat Buah Per Tanaman Panen Terung}

Hasil analisis ragam menunjukkan bahwa konsentrasi dan frekuensi pemberian giberelin $\left(\mathrm{GA}_{3}\right)$ menunjukkan interaksi nyata terhadap berat buah per tanaman per minggu panen terung pada panen ke-2 sampai dengan panen ke-5. Rata-rata berat buah per tanaman per minggu panen pada berbagai kombinasi perlakuan konsentrasi dan frekuensi pemberian giberelin $\left(\mathrm{GA}_{3}\right)$ disajikan pada Tabel 6.

Tabel 6. Rata-rata berat buah per tanaman panen (gram) (Solanum melongena L.) pada berbagai konsentrasi dan frekuensi pemberian giberelin $\left(\mathrm{GA}_{3}\right)$ pada panen ke-2 hingga panen ke-5.

\begin{tabular}{|c|c|c|c|c|c|}
\hline \multirow[b]{2}{*}{ Panen Ke - } & \multirow[b]{2}{*}{$\begin{array}{l}\text { Perlakuan } \\
\text { Kombinasi }\end{array}$} & \multicolumn{4}{|c|}{ Berat Buah Tanaman Per Minggu Panen (gram) } \\
\hline & & $\begin{array}{c}\mathrm{K}_{0} \\
(0 \mathrm{ppm})\end{array}$ & $\begin{array}{c}\mathrm{K}_{1} \\
(100 \mathrm{ppm})\end{array}$ & $\begin{array}{c}\mathrm{K}_{2} \\
(200 \mathrm{ppm})\end{array}$ & $\begin{array}{c}\mathrm{K}_{3} \\
(300 \mathrm{ppm})\end{array}$ \\
\hline \multirow{3}{*}{ Panen Ke- 2} & $\mathrm{P}_{1}(2 \mathrm{kali})$ & $388,33 \mathrm{ab}$ & $505,13 \mathrm{ab}$ & $675,43 \mathrm{~b}$ & $568,96 \mathrm{~b}$ \\
\hline & $\mathrm{P}_{2}$ (3 kali) & 318,90 a & $430,16 \mathrm{ab}$ & $494,86 a b$ & $475,98 \mathrm{ab}$ \\
\hline & $\mathrm{P}_{3}$ (4 kali) & $608,03 \mathrm{~b}$ & $493,75 \mathrm{ab}$ & $446,86 \mathrm{ab}$ & $449,36 \mathrm{ab}$ \\
\hline $\mathrm{BNJ} \%$ & \multicolumn{5}{|c|}{210,44} \\
\hline \multirow{3}{*}{ Panen Ke-3 } & $\mathrm{P}_{1}(2$ kali $)$ & 322,46 a & $696,08 \mathrm{bc}$ & $764,06 \mathrm{c}$ & $505,80 \mathrm{ab}$ \\
\hline & $\mathrm{P}_{2}(3 \mathrm{kali})$ & $362,32 \mathrm{ab}$ & $450,79 \mathrm{ab}$ & $535,30 \mathrm{~b}$ & $448,05 \mathrm{ab}$ \\
\hline & $\mathrm{P}_{3}$ (4 kali) & $359,31 \mathrm{ab}$ & $473,73 \mathrm{ab}$ & $442,45 \mathrm{ab}$ & $546,04 \mathrm{~b}$ \\
\hline $\mathrm{BNJ} \%$ & \multicolumn{5}{|c|}{186,02} \\
\hline \multirow{3}{*}{ Panen Ke- 4} & $\mathrm{P}_{1}(2$ kali) & $683,15 \mathrm{ab}$ & $774,85 \mathrm{ab}$ & $1.091,74 \mathrm{~b}$ & $689,00 \mathrm{ab}$ \\
\hline & $\mathrm{P}_{2}$ (3 kali) & 588,86 a & $812,69 a b$ & $759,54 \mathrm{ab}$ & $605,39 a b$ \\
\hline & $\mathrm{P}_{3}$ (4 kali) & $689,84 \mathrm{ab}$ & $658,80 \mathrm{ab}$ & $660,91 \mathrm{ab}$ & $624,20 \mathrm{ab}$ \\
\hline BNJ \% & \multicolumn{5}{|c|}{324,623} \\
\hline \multirow{3}{*}{ Panen Ke-5 } & $\mathrm{P}_{1}$ (2 kali) & $596,81 \mathrm{a}$ & $973,87 \mathrm{bc}$ & $1.122,02 \mathrm{c}$ & $742,77 \mathrm{ab}$ \\
\hline & $\mathrm{P}_{2}$ (3 kali) & $728,43 \mathrm{ab}$ & 806,07 b & $811,91 \mathrm{~b}$ & $765,93 a b$ \\
\hline & $\mathrm{P}_{3}$ (4 kali) & $730,87 \mathrm{ab}$ & 809,44 b & $808,59 \mathrm{~b}$ & $710,64 \mathrm{ab}$ \\
\hline
\end{tabular}

BNJ \%

204,92

Keterangan : Angka-angka yang diikuti oleh huruf yang sama tidak berbeda nyata pada uji BNJ 5\%. 
Tabel 6. menunjukkan perlakuan kombinasi antara konsentrasi dan frekuensi pemberian giberelin $\left(\mathrm{GA}_{3}\right)$ memberikan interaksi yang nyata. Hasil rata-rata dari berat buah per tanaman per minggu panen yang lebih tinggi yaitu pada perlakuan 200 ppm $\mathrm{GA}_{3}$ dan dengan frekuensi pemberian sebanyak 2 kali pada panen ke-2 hingga panen ke-5 dan masing-masing sebesar 675,43 gram, 764,06 gram, 1.091,74 gram dan 1.122,02 gram. Sedangkan berat buah per tanaman per minggu panen yang lebih rendah yaitu pada panen ke- 2 dan panen ke-4 yaitu pada perlakuan 0 ppm $\mathrm{GA}_{3}$ dengan frekuensi pemberian 3 kali yaitu 318,90 gram dan 588,86 gram. Hasil yang lebih rendah pada panen-3 dan panen-5 pada perlakuan 0 ppm $\mathrm{GA}_{3}$ dengan frekuensi pemberian 2 kali yaitu 322,46 gram dan 596,81 gram.

Perlakuan 200 ppm $\mathrm{GA}_{3}$ dengan frekuensi pemberian 2 kali memberikan berat buah per-tanaman pada panen ke-2 hingga panen ke-5 lebih berat dengan masingmasing angka yaitu 675,43 gram, 746,06 gram, 1.091,74 gram dan 1.122,02 gram dibandingkan dengan kontrol. Parameter berat buah per minggu panen terjadi peningkatan juga pada pada panen ke-2 hingga panen ke-5 dibandingkan kontrol.
Persentase peningkatan berat buah per tanaman pada minggu ke-5 panen pada perlakuan 200 ppm $\mathrm{GA}_{3}$ dengan frekuensi pemberian 2 kali dibandingkan kontrol yaitu sebesar 88\%. Pada perlakuan 200 ppm GA 3 dengan frekuensi pemberian 2 kali dibandingkan 100 ppm dengan frekuensi 2 kali menunjukkan tidak berbeda nyata. Sehingga lebih efisien penggunaan giberelin pada 100 ppm dengan 2 kali aplikasi untuk meningkatkan berat buah per tanaman.

Pada penelitian tanaman belimbing dengan pemberian konsentrasi giberelin 100 ppm dan pupuk $\mathrm{KCl} 300 \mathrm{~g} /$ tanaman memberikan hasil berat buah terberat (Wijiyanti dan Soedradjad, 2019).

\section{Pengaruh Konsentrasi dan Frekuensi Pemberian $\mathrm{GA}_{3}$ terhadap Berat Buah Total Per Tanaman Terung}

Hasil analisis ragam menunjukkan bahwa konsentrasi dan frekuensi pemberian giberelin $\left(\mathrm{GA}_{3}\right)$ menunjukkan tidak terdapat interaksi nyata terhadap berat buah total per tanaman terung. Nilai rata-rata berat buah total per tanaman akibat perlakuan kombinasi konsentrasi dan frekuensi pemberian giberelin $\left(\mathrm{GA}_{3}\right)$ pada Tabel 7.

Tabel 7. Rata-rata berat buah total per tanaman $(\mathrm{kg})$ terung (Solanum melongena $\mathrm{L}$.) pada berbagai perlakuan kombinasi konsentrasi dan frekuensi pemberian giberelin $\left(\mathrm{GA}_{3}\right)$

\begin{tabular}{|c|c|c|c|c|c|}
\hline \multirow{2}{*}{$\begin{array}{l}\text { Perlakuan } \\
\text { Kombinasi }\end{array}$} & \multicolumn{4}{|c|}{ Berat Buah Total Per Tanaman (kg) } & \multirow{2}{*}{ Rataan } \\
\hline & $\mathrm{K}_{0}(\mathrm{ppm})$ & $\mathrm{K}_{1}(100 \mathrm{ppm})$ & $\mathrm{K}_{2}(200 \mathrm{ppm})$ & $\mathrm{K}_{3}(300 \mathrm{ppm})$ & \\
\hline $\mathrm{P}_{1}(2$ kali $)$ & 2,00 & 3,34 & 4,12 & 2,65 & 3,03 \\
\hline $\mathrm{P}_{2}(3 \mathrm{kali})$ & 2,04 & 2,85 & 2,89 & 2,71 & 2,62 \\
\hline $\mathrm{P}_{3}(4$ kali) & 2,29 & 2,60 & 2,64 & 2,46 & 2,5 \\
\hline Rataan & 2,11 & 2,93 & 3,22 & 2,61 & \\
\hline BNJ 5\% & & \\
\hline
\end{tabular}

Keterangan : tn : tidak nyata

Tabel 7. menunjukkan perlakuan kombinasi antara konsentrasi dan frekuensi pemberian giberelin $\left(\mathrm{GA}_{3}\right)$ tidak terdapat interaksi yang nyata. Hasil rata-rata dari berat buah total per tanaman terung yang lebih tinggi yaitu pada perlakuan $200 \mathrm{ppm} \mathrm{GA}_{3}$ dengan frekuensi pemberian 2 kali pada tanaman terung yaitu $4,12 \mathrm{~kg}$. Sedangkan berat buah total per-tanaman terung yang lebih rendah yaitu pada perlakuan 0 ppm $\mathrm{GA}_{3}$ dengan frekuensi pemberian 2 kali yaitu sebesar $2 \mathrm{~kg}$. Persentase peningkatan berat buah total per tanaman sebesar $106 \%$ dibandingkan kontrol. Pemberian giberelin berpengaruh terhadap bobot buah total tanaman terung (Arsy dan Barunawati, 2018). Giberelin mampu membantu meningkatkan pembelahan dan pembesaran sel sehingga 
ukuran buah bertambah (Muhyidin et al., 2018). Aplikasi giberelin juga telah terbukti meningkatkan ukuran buah beri (Weaver and McCune, 1959).

\section{Pengaruh Konsentrasi dan Frekuensi Pemberian GA3 terhadap Fruit Set Terung}

Hasil analisis ragam menunjukkan bahwa konsentrasi dan frekuensi pemberian giberelin $\left(\mathrm{GA}_{3}\right)$ menunjukkan tidak terdapat interaksi nyata terhadap Fruit Set terung. Nilai rata-rata Fruit Set akibat perlakuan konsentrasi dan frekuensi pemberian giberelin $\left(\mathrm{GA}_{3}\right)$ pada Tabel 8.

Tabel 8. Rata-rata fruit set terung (Solanum melongena L.) pada berbagai konsentrasi dan frekuensi pemberian giberelin $\left(\mathrm{GA}_{3}\right)$

\begin{tabular}{|c|c|c|c|c|c|}
\hline \multirow{2}{*}{$\begin{array}{l}\text { Perlakuan } \\
\text { Kombinasi }\end{array}$} & \multicolumn{3}{|c|}{ Fruit Set (\%) } & \multirow[b]{2}{*}{$\mathrm{K}_{3}(300 \mathrm{ppm})$} & \multirow[b]{2}{*}{ Rataan } \\
\hline & $\mathrm{K}_{0}(\mathrm{ppm})$ & $\mathrm{K}_{1}(100 \mathrm{ppm})$ & $\mathrm{K}_{2}(200 \mathrm{ppm})$ & & \\
\hline $\mathrm{P}_{1}(2$ kali $)$ & $69,07 \%$ & $76,08 \%$ & $81,26 \%$ & $77,78 \%$ & $76,05 \%$ \\
\hline $\mathrm{P}_{2}$ (3 kali) & $73,89 \%$ & $80,37 \%$ & $63,91 \%$ & $77,59 \%$ & $73,94 \%$ \\
\hline $\mathrm{P}_{3}(4$ kali) & $75,32 \%$ & $71,22 \%$ & $68,73 \%$ & $71,66 \%$ & $71,73 \%$ \\
\hline Rataan & $72,76 \%$ & $75,89 \%$ & $71,3 \%$ & $75,68 \%$ & \\
\hline
\end{tabular}

Keterangan : tn : tidak nyata

Tabel 8 menunjukkan perlakuan kombinasi antara konsentrasi dan frekuensi pemberian giberelin $\left(\mathrm{GA}_{3}\right)$ memberikan tidak adanya interaksi yang nyata. Hasil rata-rata dari Fruit Set terung yang lebih tinggi yaitu pada perlakuan 200 ppm $\mathrm{GA}_{3}$ dengan frekuensi pemberian 2 kali pada tanaman terung yaitu $81,26 \%$. Sedangkan Fruit Set terung yang lebih rendah yaitu pada perlakuan 200 ppm $\mathrm{GA}_{3}$ dan frekuensi pemberian 3 kali aplikasi yaitu sebesar 63,91 $\%$. Persentase peningkatan fruit set dibandingkan kontrol yaitu 17,64\%.

Peningkatan jumlah bunga yang terbentuk serta buah menyebabkan tingginya persentase fruit set. Persentase fruit set lebih tinggi menandakan bahwa konsentrasi tinggi yang diaplikasikan pada saat awal berbunga dan berbuah dapat meningkatkan persentase fruit set pada tanaman (Yasmin et al., 2014).

Berdasarkan variabel hasil, aplikasi konsentrasi 100 ppm $\mathrm{GA}_{3}$ dengan 2 kali aplikasi merupakan pemberian giberelin dengan konsentrasi dan frekuensi waktu yang tepat. Pemberian giberelin secara eksogen dapat efektif apabila diberikan sesuai dengan kebutuhan tanaman. Aplikasi hormon giberelin dengan konsentrasi yang terlalu rendah dan frekuensi rendah tidak efektif begitu pula dengan konsentrasi tinggi dan frekuensi tinggi dapat menghambat pertumbuhan dan produksi tanaman terung.

Giberelin yang diaplikasikan pada tanaman terung menyebabkan buah tidak mengalami kerontokan dan memperbanyak jumlah buah pada tanaman, sehingga berat buah pun bertambah dan jumlah buah meningkat. Pengaturan giberelin dalam perkembangan buah dimulai dengan kemampuannya untuk merangsang pembentukan buah. Pengaplikasian giberelin akan mampu menginduksi sel sehingga ukuran buah menjadi lebih besar. Pemberian giberelin mengakibatkan kegiatan metabolisme meningkat, laju fotosintesis meningkat, dengan demikian karbohidrat yang terbentuk akan meningkat yang dimanfaatkan untuk perkembangan buah. Giberelin juga mengaktifkan meristem sub apikal dan menghasilkan bolting yang memulai pengeluaran bunga (Rolistyo et al., 2014). Aplikasi giberelin memberikan stimulasi pada pertumbuhan, pembungaan dan fruit set (Rappaport, 2008). 
Tabel 9. Gambar buah terung pada berbagai kombinasi perlakuan

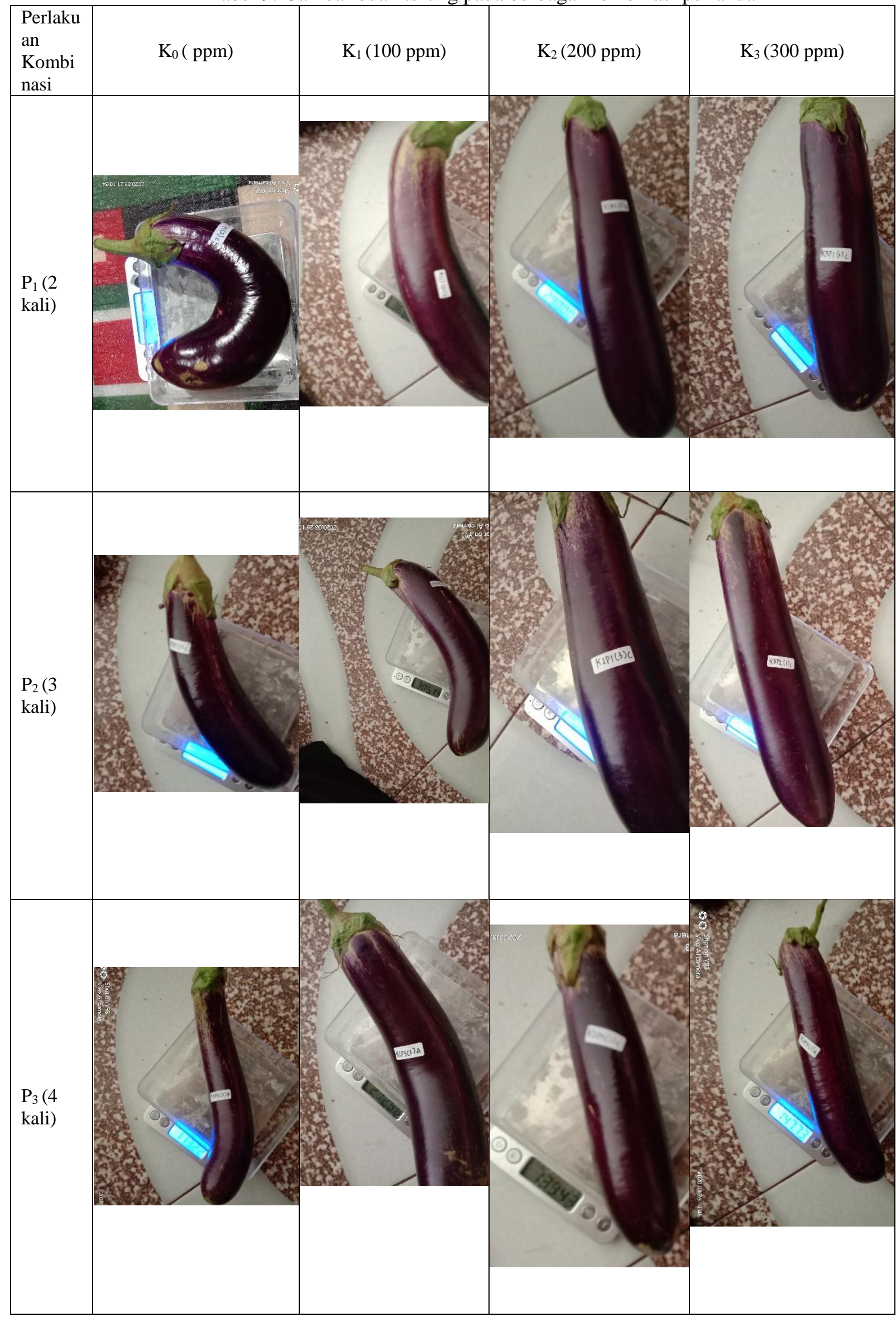


Terbentuknya buah berawal dari adanya bunga. Peningkatan jumlah bunga disebabkan karena giberelin yang diaplikasikan saat awal berbuah mampu meningkatkan pembungaan dan menurunkan absisi bunga maupun buah, sehingga total jumlah bunga meningkat. Pertumbuhan buah menuntut nutrisi mineral yang banyak, menyebabkan terjadinya mobilisasi dan transport dari bagian vegetatif ke tempat perkembangan buah dan biji. Adanya penambahan giberelin saat awal terbentuknya buah mampu membantu meningkatkan pembelahan dan pembesaran sel sehingga ukuran buah bertambah (Yasmin et al., 2014).

Giberelin dan auksin tampaknya berinteraksi untuk mengatur pertumbuhan buah melalui pembelahan dan ekspansi sel (Serrani et al., 2007). Kadar giberelin pada tanaman dapat meningkatkan kadar auksin. Hal ini karena giberelin mampu memacu pembentukan enzim proteolitik. Enzim ini berfungsi untuk melunakkan dinding sel pada tanaman. Dinding sel tanaman yang melunak dapat mengakibatkan lepasnya amino triptofan. Senyawa ini merupakan prekursor auksin, sehingga kadar auksin dapat meningkat. Auksin berfungsi pada pembelahan sel, sedangkan giberelin berfungsi pada pembentangan sel. Sehingga kerja yang sinergi antara auksin dengan giberelin tersebut membuat ukuran sel bertambah. Maka penambahan hormon tumbuh giberelin dengan cara eksogen mampu menambah ukuran sel yang diakibatkan karena terjadinya pembelahan serta pembentangan sel. Dinding sel yang mengalami kelemahan ikatan antar dinding sel, mendorong dinding sel serta membran sel bertambah besar (Wijiyanti dan Soedradjad, 2019).

\section{SIMPULAN}

Tanaman terung yang diberi perlakuan 200 ppm GA 3 dengan 2 kali aplikasi terjadi interaksi terhadap parameter tinggi tanaman pada umur 28-56 hst dengan rata-rata hasil
$135,16 \mathrm{~cm}$ dan mengalami peningkatan hingga 92,05\%, jumlah daun pada umur 3549 hst dengan hasil rata-rata 31 helai dan mengalami peningkatan hingga 93,75\%, umur berbunga dimana berbunga lebih awal pada 36 hst meningkatkan $14,37 \%$, jumlah bunga dengan rata-rata total 27 bunga dan meningkat hingga 58,82\%, jumlah buah total mengalami peningkatan $80 \%$, jumlah berat buah total per tanaman meningkat $106 \%$ dan fruit set meningkat $17,64 \%$. Pada komponen hasil, perlakuan 100 ppm $\mathrm{GA}_{3}$ dengan 2 kali aplikasi menunjukkan tidak berbeda nyata dengan 200 ppm dengan 2 kali aplikasi. Sehingga aplikasi pemberian 100 ppm $\mathrm{GA}_{3}$ dengan 2 kali aplikasi dapat direkomendasikan pada budi daya tanaman terung untuk meningkatkan hasil.

\section{DAFTAR PUSTAKA}

Achard, Patrick et al. 2008. "The ColdInducible CBF1 Factor-Dependent Signaling Pathway Modulates the Accumulation of the GrowthRepressing DELLA Proteins via Its Effect on Gibberellin Metabolism." Plant Cell 20(8): 2117-29.

Arsy, Andra Fatiqha, and Nunun Barunawati. 2018. "Pengaruh Aplikasi GA3 Terhadap Pertumbuhan Dan Hasil Dua Varietas Tanaman Terung ( Solanum Melongena L .)." Jurnal Produksi Tanaman 6(7): 1250-57.

Bose, Nanda. 1959. "Effect of Gibberellin on The Growth of Pollen Tubes)." Nature (4698): 1577.

Firmansyah, Imam; Syakir, Muhammad; Lukman, Liferdi. 2017. "Pengaruh Kombinasi Dosis Pupuk N, P, Dan K Terhadap Pertumbuhan Dan Hasil Tanaman Terung (Solanum Melongena L.) [The Influence of Dose Combination Fertilizer N, P, and K on Growth and Yield of Eggplant Crops (Solanum Melongena L.)]." Hortikultura 27(1): 69-78.

http://dx.doi.org/10.21082/jhort.v27n1. 2017.p69-78. 
Frasetya, B., N. Nurfatha, K. Harisman, and M. Subandi. 2018. "Growth and Yield of Hydroponic Watermelon with Straw Compost Substrate and Gibereline (GA3) Application." IOP Conference Series: Materials Science and Engineering 434(1): 1-6.

Muhyidin, Hidayatul, Titiek Islami, and Moch Dawam Maghfoer. 2018. 'Pengaruh Konsentrasi Dan Waktu Pemberian Giberelin Pada Pertumbuhan Dan Hasil Tanaman Tomat (Lycopersicon Esculentum Mill.).” Jurnal Produksi Tanaman 6(6): 1147-54.

Pertiwi, Novi Mega, M. Tahir, and Made Same. 2016. "Respons Pertumbuhan Benih Kopi Robusta Terhadap Waktu Perendaman Dan Konsentrasi Giberelin (GA3) (The Growth Responses of the Robusta Coffee Seed toward of Soaking Time and Concentration of Giberelin [GA 3 ])." Jurnal Agro Industri Perkebunan 4(1): 1-11.

Rahman Zain, Abdullah, Zainuddin Basri, and Iskandar Lapanjang. 2015. "Pembentukan Buah Terung (Solanum Melongena L.) Partenokarpi Melalui Aplikasi Berbagai Konsentrasi Giberelin.” Jurnal Sains Dan Teknologi Tadulako 4(2): 60-67.

Rappaport, Lawrence. 2008. "Effect of Gibberellin on Growth, Flowering and Fruiting of The Earlypak Tomato, Lycopersicum Esculentum." Plant Physiology: 440-44.

Rolistyo, Alpano, Sunaryo Sunaryo, and Tatik Wardiyati. 2014. "Pengaruh Pemberian Giberelin Terhadap Produktivitas Dua Varietas Tanaman Tomat ( Lycopersicum Esculentum Mill .)." Jurnal Produksi Tanaman 2(6): 457-63.

Serrani, Juan C., Mariano Fos, Alejandro Atarés, and José L. García-Martínez. 2007. "Effect of Gibberellin and Auxin on Parthenocarpic Fruit Growth Induction in the $\mathrm{Cv}$ Micro-Tom of Tomato." Journal of Plant Growth Regulation 26(3): 211-21.

Seswita, Deliah. 2020. "Penggunaan Air
Kelapa Sebagai Zat Pengatur Tumbuh Pada Multiplikasi Tunas Temulawak (Curcuma Xanthorrhiza Roxb.) in Vitro." Jurnal Penelitian Tanaman Industri 16(4): 135-40.

Setiawan, Heru, Ahmad Junaedi, and M. Rahmad Suhartanto. 2019. "Manajemen Produksi Terung (Solanum Melongena L.) Hidroponik Dalam GH Dengan Aspek Khusus Pemupukan Di Belanda." Buletin Agrohorti 7(1): 84-92.

Sriyanto, Doni, Puji Astuti, and Aksa Pinaringan Sajalu. 2015. "Pengaruh Dosis Pupuk Kandang Sapi Terhadap Pertumbuhan Dan Hasil Tanaman Terung Ungu Dan Terung Hijau (Solanum Melongena L.)." Agrifor XIV(1): 39-44.

Subdirektorat Statistik Hortikulura. 2018. "Statistik Tanaman Sayuran Dan Buahbuahan Semusim Indonesia 2017.Pdf." Badan Pusat Statistik: 101.

Uluputty, Muhamad Riadh. 2014. "Gulma Utama Pada Tanaman Terung Di Desa Wanakarta Kecamatan Waeapo Kabupaten Buru.' Agrologia 3(1): 37-43.

Weaver, Robert J., and Stanley B. McCune. 1959. "Effect of Gibberellin on Seedless Vitis Vinifera." HILGARDIA 29(6): 247-75.

Wijiyanti, Nur, and Raden Soedradjad. 2019. "PENGARUH PEMBERIAN PUPUK KALIUM DAN HORMON GIBERELIN TASIKMADU DI KABUPATEN TUBAN Effect of Potassium Fertilizer and Giberelline Hormone on Quantity and Quality of Tasikmadu Starfruit in Tuban Regency Nur Wijiyanti Dan Raden Soedradjad * Program Studi Agr." Berkala Ilmiah PERTANIAN 2(4): 169-72.

Yasmin, Shofiah, Tatik Wardiyati, and Koesriharti. 2014. "Pengaruh Perbedaan Waktu Aplikasi Dan Konsentrasi Giberelin (GA3) Terhadap Pertumbuhan Dan Hasil Tanaman Cabai Besar (Capsicum Annuum L.)." Produksi tanaman 2 Nomor 5: 395-403. 